\title{
Pharmacokinetics of the $\mathbf{S}(+)$ and $\mathbf{R}(-)$ enantiomers of vigabatrin during chronic dosing in a patient with renal failure
}

\author{
Evelyne Jacqz-Aigrain,' Marianne Guillonneau,' Elisabeth Rey, ${ }^{3}$ Marie-Alice Macher, ${ }^{2}$ Christine Montes,' \\ Catherine Chiron ${ }^{4} \&$ Chantal Loirat $^{2}$ \\ Department of ${ }^{1}$ Pediatric Clinical Pharmacology and ${ }^{2}$ Nephrology, Hôpital Robert Debré and Department of ${ }^{3}$ Pediatric and Perinatal Pharmacology and \\ ${ }^{4}$ Neuropediatry, Hôpital Saint-Vincent-de-Paul, Paris, France
}

\begin{abstract}
Aims To study the pharmacokinetics of vigabatrin in a patient affected with tuberous sclerosis who developed major agitation and aggression, while receiving vigabatrin orally $(1.5 \mathrm{~g}$ every $12 \mathrm{~h})$ and in whom impaired renal function was diagnosed.

Methods The patient received vigabatrin $\left(0.5 \mathrm{~g}\right.$ day $\left.^{-1}\right)$. A pharmacokinetic study of the $\mathrm{S}(+)$ and $\mathrm{R}(-)$ enantiomers of vigabatrin was performed before and during dialysis. Plasma concentrations were measured at $0,1,2,3,4,6,12,18$ and 24 h by a specific GCMS assay.

Results Before dialysis, the maximum and minimun plasma concentrations of vigabatrin at steady-state were lower for the $\mathrm{S}(+)$ than for the $\mathrm{R}(-)$ enantiomer, while the apparent oral clearance was higher for the $\mathrm{S}(+)$ than for the $\mathrm{R}(-)$ enantiomer $\left(2.97\right.$ vs $\left.0.481 \mathrm{~h}^{-1}\right)$. In addition, the haemodialysis clearance was similar for the two enantiomers (4.96 vs $\left.5.151 \mathrm{~h}^{-1}\right)$.

Conclusions Vigabatrin is an irreversible inhibitor of GABA-transaminase, effective in the treatment of drug-resistant epilepsy and reported to be eliminated unchanged by renal excretion. Although vigabatrin is known to have stereoselective kinetics, the difference in plasma dry concentrations and pharmacokinetics of the $\mathrm{S}(+)$ and $\mathrm{R}(-)$ enantiomers that we observed during long term administration at high doses in a patient with impaired renal function, has not been reported before. The question remains of the potential toxicity of the high levels of the $\mathrm{R}(-)$ enantiomer.
\end{abstract}

Keywords: vigabatrin, enantiomers, renal failure

\section{Introduction}

Vigabatrin ( $\gamma$-vinyl GABA) is a selective, enzyme-activated, irreversible inhibitor of GABA-transaminase, the enzyme catalysing the catabolism of the neurotransmitter GABA [1, 2]. Vigabatrin produces a dose-related increase in CSF GABA [3]. It reduces the frequency of partial seizures by at least $50 \%$ in about half of adult and paediatric patients with drug-resistant epilepsy [4-7].

Vigabatrin is a racemic mixture of two enantiomers $\mathrm{S}(+)$ and $\mathrm{R}(-)$, the $\mathrm{S}(+)$ enantiomer being the active compound. The drug is reported not to be protein bound and to be eliminated unchanged by renal excretion [8, 9]. The pharmacokinetics of the two enantiomers are very similar $[10,11]$.

Here, we describe a 15 year old epileptic patient, who was treated with vigabatrin for more than 6 months at the standard dose of $3 \mathrm{~g} \mathrm{day}^{-1}$ and was admitted to hospital with end-stage renal failure. A pharmacokinetic study of the drug was performed before the decision to dialyse and during a dialysis session. The pharmacological data demonstrated major differences in the disposition of the two enantiomers.

Correspondence Dr E. Jacqz Aigrain, Service de Pharmacólogie Clinique, Hôpital Robert Debré, 48 Boulevard Sérurier, 75019 Paris, France.

\section{Methods}

Patient

The patient, born in 1980, was affected with tuberous sclerosis, diagnosed at the age of 3 months when she developed partial seizures, with secondary generalized tonicclonic seizures. From 1980 to 1993, she received various anti-epileptic drugs, including carbamazepine alone or in combination with phenobarbitone, with phenytoin or clobazam, without complete remisson of seizures. She also presented with behavioural disturbances with social disability. In 1993, vigabatrin $\left(3 \mathrm{~g} \mathrm{day}^{-1}\right)$ was added to carbamazepine $\left(600 \mathrm{mg} \mathrm{day}^{-1}\right)$. The frequency of seizures decreased to 2 to 3 per week. Sixteen months later, the patient complained of fatigue and presented with nausea and vomiting and she developed important additional behavioural changes, while routine laboratory tests revealed that serum creatinine was $770 \mu \mathrm{mol}^{-1}$. At admission, her weight was $64 \mathrm{~kg}$, clinical examination revealed major agitation and aggression, alternating with phases of confusion and drowsiness. Laboratory tests included haemoglobin, $5.4 \mathrm{~g} \mathrm{dl}^{-1}$, serum creatinine $848 \mathrm{moll}^{-1}$ and creatinine clearance was $10 \mathrm{ml} \mathrm{min}^{-1}$ $\left(1.73 \mathrm{~m}^{2-1}\right)$. The patient received a blood transfusion and erythropoietin. Renal echography revealed multiple microcysts and end-stage renal failure was attributed to tuberous 
sclerosis. At that time, she was receiving vigabatrin (1.5 g every $12 \mathrm{~h})$, carbamazepine (200 $\mathrm{mg}$ every $12 \mathrm{~h}$ ) and pipamperone (40 mg every $12 \mathrm{~h}$ ). Plasma concentrations of carbamazepine and carbamazepine epoxide were 6.9 and $1.9 \mathrm{mg} \mathrm{l}^{-1}$ respectively, while plasma concentrations of the $\mathrm{S}(+)$ and $\mathrm{R}(-)$ enantiomers of vigabatrin were 69 and $217 \mathrm{mg} \mathrm{l}^{-1}$. The neurologic manifestations were attributed to vigabatrin and the dose was decreased to $1 \mathrm{~g}$ every $12 \mathrm{~h}$ then to $0.5 \mathrm{~g}$ daily. Renal dialysis was performed, on the basis of three sessions per week. The patient continued to receive vigabatrin $\left(0.5 \mathrm{~g}\right.$ day $\left.^{-1}\right)$ and carbamazepine $(200 \mathrm{mg}$ every $12 \mathrm{~h}$ ). Neurologic symptoms resolved following dosage reduction and dialysis. She is now treated with vigabatrin 0.75 g day $^{-1}$.

\section{Drug analysis}

Blood samples $(1 \mathrm{ml})$ were collected in heparinized tubes, centrifuged and kept frozen $\left(-20^{\circ} \mathrm{C}\right)$ until analysis. The enantiomers of vigabatrin were measured using a specific gas chromatography mass spectrometry procedure [10]. The coefficients of variation were less than $13.8 \%$ at all concentrations from 0.5 to $50 \mu \mathrm{g} \mathrm{ml}^{-1}$ for both enantiomers.

Pharmacokinetics in end-stage renal failure Blood samples were collected before drug administration and at 1, 2, 3, 4, 6, 12, 18 and $24 \mathrm{~h}$ after administration. Pharmacokinetic analysis was performed with use of compartment independent methods. The oral apparent clearance was determined using the following relationship:

$$
\mathrm{CL} / F=(\operatorname{Dose}(\mathrm{E}) / \tau) /(\mathrm{AUC} / \tau)
$$

in which $F$ is the bioavailability factor, $\mathrm{E}$ is the dose of each enantiomer (i.e. half the oral administered dose), $\tau$ is the interval between two administrations, AUC is the area under the plasma concentration time curve between two administrations at steady-state.

Haemodialysis plasma clearance Haemodialysis clearance (CLHD) was calculated using the following relationship:

$$
\mathrm{CL}_{\mathrm{HD}}=\left[\left(\mathrm{Q}_{\mathrm{P}} \times C_{\mathrm{A}}\right)-\left(\mathrm{Q}_{\mathrm{P}}-\mathrm{Q}_{\mathrm{U}}\right) \times C_{\mathrm{V}}\right] / C_{\mathrm{A}}
$$

where $C_{\mathrm{A}}$ and $C_{\mathrm{V}}$ are the concentrations in the arterial and venous segments of the blood flow loop, $\mathrm{Q}_{\mathrm{P}}$ is the average plasma flow rate (equal to: blood flow rate $\times$ $\left(1\right.$ - haematocrit)) and $\mathrm{QU}_{\mathrm{U}}$ is the ultrafiltrate flow rate.

\section{Results}

The pharmacokinetic parameters of the $\mathrm{S}(+)$ and $\mathrm{R}(-)$ enantiomers of vigabatrin were determined at steady-state, after 22 days of treatment with an oral dose of $0.5 \mathrm{~g} \mathrm{day}^{-1}$ (Table 1 and Figure 1). The $C_{\min }$ values were 2.2 and $17.4 \mathrm{mg} \mathrm{l}^{-1}$ for the $\mathrm{S}(+)$ and $\mathrm{R}(-)$ enantiomers respectively. The $C_{\max }$ value of the $\mathrm{S}(+)$ enantiomer was lower than that of the $\mathrm{R}(-)$ enantiomer (5.9 vs $27.8 \mathrm{mg} \mathrm{l}^{-1}$ ) and the difference $\left(C_{\max }\right.$ value $-C_{\min }$ value) was 3.7 and $10.4 \mathrm{mg}^{-1}$ for the $\mathrm{S}(+)$ and $\mathrm{R}(-)$ enantiomers respectively. In addition, the apparent oral clearance was much higher for the $\mathrm{S}(+)$ than for the $\mathrm{R}(-)$ enantiomer. Because
Table 1 Pharmacokinetic parameters of the $\mathrm{S}(+)$ and $\mathrm{R}(-)$ enantiomers of vigabatrin in a patient with end-stage renal failure, before and during dialysis.

\begin{tabular}{lccc}
\hline & $S(+)$ & $R(-)$ & $S(+) / R(-)$ ratio \\
\hline Not dialyzed & & & \\
$C_{\max }\left(\mathrm{mg}^{-1}\right)$ & 5.9 & 27.8 & 0.21 \\
$C_{\min }\left(\mathrm{mg}^{-1}\right)$ & 2.2 & 17.4 & \\
$C_{\max }-C_{\min }\left(\mathrm{mg} 1^{-1}\right)$ & 3.7 & 10.4 & $/$ \\
$t_{\max }(\mathrm{h})$ & 2 & 2 & $/$ \\
AUC $24 \mathrm{~h}\left(\mathrm{mg}{ }^{-1} \mathrm{~h}\right)$ & 84 & 523 & 0.16 \\
$\mathrm{CL} / F\left(1 \mathrm{~h}^{-1}\right)$ & 2.97 & 0.48 & 6.19 \\
Dialyzed & & & \\
Amount recovered over $4 \mathrm{~h}$ & & & \\
$\quad$ in the dialysate (mg) & 102 & 351 & 0.29 \\
$\mathrm{CL}_{\mathrm{HD}}\left(1 \mathrm{~h}^{-1}\right)$ & 4.96 & 5.15 & 0.96 \\
\hline
\end{tabular}

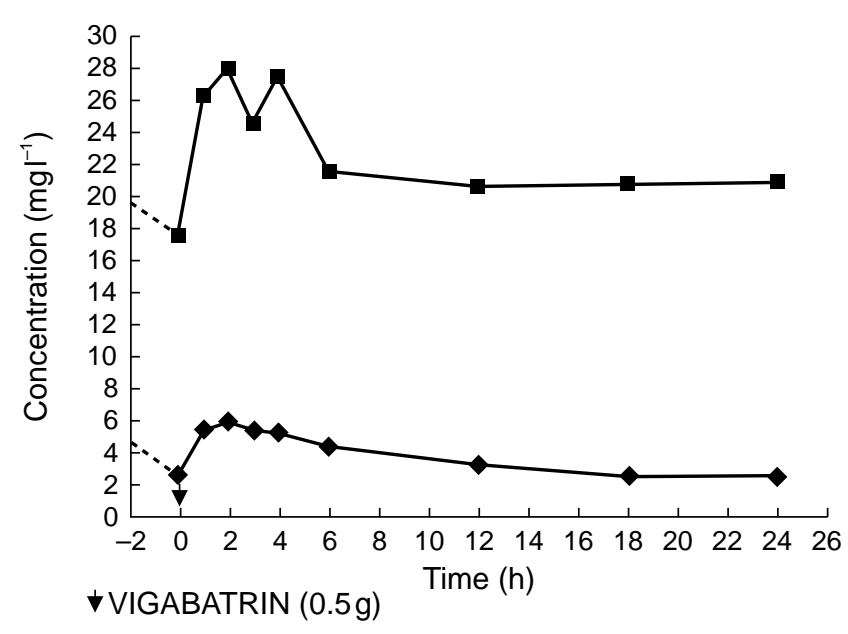

Figure 1 Pharmacokinetic profile of the $\mathrm{S}(+)(\bullet)$ and $\mathrm{R}(-)$ $(\boldsymbol{\square})$ enantiomers of vigabatrin, in a patient with end-stage renal failure, receiving $0.5 \mathrm{~g} \mathrm{day}^{-1}$ after chronic overdose.

the duration of sampling was limited to $24 \mathrm{~h}$, the terminal half-life could only be estimated for the $\mathrm{S}(+)$ enantiomer and it was $16 \mathrm{~h}$. It is certainly much longer for the $\mathrm{R}(-)$ enantiomer.

The patient underwent haemodialysis sessions of $4 \mathrm{~h}$ duration. The haemodialysis clearance was measured while the patient was receiving $0.5 \mathrm{~g}$ every $24 \mathrm{~h}\left(7.8 \mathrm{mg} \mathrm{kg}^{-1}\right.$ day $^{-1}$ ) and is presented in Table 1 . The amount of $\mathrm{R}(-)$ enantiomer recovered in the dialysate over $4 \mathrm{~h}$ was $351 \mathrm{mg}$, while it was $102 \mathrm{mg}$ for the $\mathrm{S}(+)$ enantiomer. The haemodialysis clearance was similar for the two enantiomers: $4.961 \mathrm{~h}^{-1}$ for the $\mathrm{S}(+)$ and $5.151 \mathrm{~h}^{-1}$ for the $\mathrm{R}(-)$ enantiomer.

\section{Discussion}

Vigabatrin, a structural analogue of the inhibitory neurotransmetter gamma-aminobutyric acid (GABA), is a racemic mixture of two enantiomers $\mathrm{S}(+)$ and $\mathrm{R}(-)$. The $\mathrm{S}(+)$ enantiomer is pharmacologically active while the $\mathrm{R}(-)$ enantiomer is inactive.

Vigabatrin is normally well tolerated and the incidence of side-effects appears low. Among them, the most frequent in children are agitation and hyperkinesia, estimated to occur in 15 to $25 \%$ of epileptic patients [5]. It usually appears 
during the first months of treatment but often disappears by reducing the dose. It mainly involves patients with mental retardation and preexisting hyperkinesia [12-15]. As previously stated, our patient developed irritability, agitation and anxiety progressing to extreme aggression. The overall incidence of such disorder is approximately 1.5\%. She had all the predisposing factors to hyperkinesia on vigabatrin, i.e lesions of the central nervous system, mental retardation and high doses of the drug [12].

The patient was treated chronically with standard doses of vigabatrin while developing progressive renal failure and major neurotoxicity. She had high plasma concentrations of the active $\mathrm{S}(+)$ enantiomer but in addition the $\mathrm{R}(-)$ enantiomer accumulated to levels higher than that of the $\mathrm{S}(+)$ enantiomer.

The disposition of vigabatrin has been studied in most cases after administration of a single oral dose of the racemate. The drug is reported to be well absorbed, not bound to plasma proteins, and mainly eliminated unchanged in urine $[8,9]$. Its elimination half-life is approximately $7 \mathrm{~h}$. A multiple dose study, limited to 4.5 days did not demonstrate changes in the pharmacokinetics of racemic vigabatrin [8].

Data on the pharmacokinetics of the individual $\mathrm{S}(+)$ and $\mathrm{R}(-)$ enantiomers are only limited. Their disposition studied in healthy volunteers [11], in pediatric epileptic patients [10] and neonates [16] is reported to be very similar. However, during single dose studies, in adults and children with normal renal function, the peak plasma concentrations of the $\mathrm{R}(-)$ enantiomer were consistently two times higher while the recovery of unchanged drug in urine was lower for the $\mathrm{S}(+)$ than for the $\mathrm{R}(-)$ enantiomer [11]. The major differences that we observed in the disposition of the two enantiomers were unexpected but in agreement with stereoselective kinetics, probably of renal elimination. However, an effect on hepatic metabolism or absorption cannot be ruled out.

There is no difference in the pharmacokinetics of vigabatrin between normal volunteers and epileptic patients under add-on therapy for at least 4 weeks [7]. The pharmacokinetics of the drug is altered in patients with reduced renal function and dosage reduction is necessary to avoid drug accumulation leading to toxicity $[17,18]$. During chronic overdosage associated with renal failure, the difference in the pharmacokinetics of the two enantiomers is unexplained and the potential therapeutic and toxic consequences of the high $\mathrm{R}(-)$ enantiomer concentrations remain to be investigated [19].

\section{References}

1 Rimmer E, Kongola G, Richens A. Inhibition of the enzyme, GABA-aminotransferase in human platelets by vigabatrin, a potential antiepileptic drug. Br J Clin Pharmacol 1988; 25: 251-259.

2 Grant SM, Heel RC. Vigabatrin: a review of its pharmacodynamic and pharmacokinetic properties and therapeutic potential in epilepsy and disorders of motor control. Drugs 1991; 41: 889-926.

3 Schechter PJ, Hanke NFJ, Grove J, Huebert N, Sjoerdsma A. Biochemical and clinical effects of gamma-vinyl GABA in patients with epilepsy. Neurology 1984; 34: 182-185.

4 Livingston JH, Beaumont D, Arzimanoglou A, Aicardi $\mathrm{J}$. Vigabatrin in the treatment of epilepsy in children. $\mathrm{Br}$ J Clin Pharmacol 1989; 27: 109S-112S.

5 Luna D, Dulac O, Pajot N, Beaumont D. Vigabatrin in the treatment of childhood epilepsies: a single blind placebo controlled study. Epilepsia 1989; 30: 430-437.

6 Chiron C, Dulac O, Beaumont D, Palacias L, Pajot N, Mumford J. Therapeutic trial of vigabatrin in refractory infantile spasms. J Child Neurol 1991; 6: S52-S59.

7 French JA, Mosier M, Walker S, Sommerville K, Sussman N, Vigabatrin Protocol 024 Investigative Cohort. A double-blind, placebo-controlled study of vigabatrin three $\mathrm{g} /$ day in patients with uncontrolled complex partial seizures. Neurology 1996; 46: $54-61$.

8 Hoke JF, Yuh L, Antony KK, Okerholm RA, Elberfeld JM, Sussman NM. Pharmacokinetics of vigabatrin following single and multiple oral doses in normal volunteers. J Clin Pharmacol 1993; 33: 458-462.

9 Durham SL, Hoke JF, Chen TM. Pharmacokinetics and metabolism of vigabatrin following a single oral dose of [14C vigabatrin in healthy male volunteers. Drug Metab Disp. 1993; 21: 480-484.

10 Rey E, Pons G, Richard MO, et al. Pharmacokinetics of the individual enantiomers of vigabatrin (gamma-vinyl GABA) in epileptic children. BrJ Clin Pharmacol 1990; 30: 253-257.

11 Haegele KD, Schechter PJ. Kinetics of the enantiomers of vigabatrin after an oral dose of the racemate or the active S-enantiomer. Clin Pharmacol Ther 1986; 40: 581-586.

12 Sander JWAS, Hart YM. Vigabatrin and behaviour disturbances. Lancet 1990; 335: 57.

13 Robinson MK, Richens A, Oxley R. Vigabatrin and behaviour disturbances. Lancet 1990; ii: 504.

14 Brodie MJ, McKee PJW. Vigabatrin and psychosis. Lancet 1990; i: 1279 .

15 Dam M. Vigabatrin and behaviour disturbances. Lancet 1990; i: 605 .

16 Vauzelle-Kervroedan F, Pons G, Rey E, et al. Pharmacokinetics of the individual enantiomers of vigabatrin in neonates with uncontrolled seizures. Fundam Clin Pharmacol 1993; 7: 585.

17 Haegele KD, Huebert ND, Ebel M, Tell GP, Schechter PJ. Pharmacokinetics of vigabatrin: implications of creatinine clearance. Clin Pharmacol Ther 1988; 44: 558-565.

18 Hutcheson SJ, Yu DK, Szylleyko O, et al. Pharmacokinetics of vigabatrin in patients with varying degrees of renal function. Epilepsia 1993; 34: 106.

19 Williams K, Lee E. Importance of drug enantiomers in clinical pharmacology. Drugs 1985; 30: 333-354.

(Received 9 September 1996, accepted 18 March 1997) 